\title{
Impact of Consciousness Healing Treatment on Physical, Thermal and Spectroscopic Properties of Copper Chloride
}

\author{
Mahendra Kumar Trivedii ${ }^{1}$ and Snehasis Jana ${ }^{2 *}$ \\ ${ }^{1}$ Trivedi Global, Inc., Henderson, Nevada, USA \\ ${ }^{2}$ Trivedi Science Research Laboratory Pvt. Ltd., Maharashtra, India
}

Submission: January 19, 2021; Published: March 09, 2021

*Corresponding author: Snehasis Jana, Trivedi Science Research Laboratory Pvt. Ltd., Maharashtra, India

\begin{abstract}
Copper plays an important role in development, normal functioning, iron absorption and transport, and immune function in human body. It is given in the supplements in the form of copper chloride to avoid the cupper deficiency associated symptoms. This study was designed to analyse the impact of the Trivedi Effect ${ }^{\circledR}$-Energy of Consciousness Healing Treatment on copper chloride regarding its physical, thermal, and spectral properties. For this, the copper chloride sample was distributed in two halves, in which one part was termed as control sample and kept untreated. The other part was named as Biofield Energy Treated sample and it received the Trivedi Effect ${ }^{\circledR}$-Biofield Energy Healing Treatment remotely by the renowned Biofield Energy Healer, Mr. Mahendra Kumar Trivedi. Consequently, the control and treated samples were analyzed for any change with the help of PXRD, DSC, TGA/DTG, FT-IR, and UV-Vis analytical techniques. The PXRD analysis of the treated sample showed the significant changes in the crystallite sizes from $-8.35 \%$ to $30.78 \%$ along with $5.27 \%$ increase in the average crystallite size compared with the control sample. Similarly, the relative peak intensities of the Biofield Energy Treated sample showed alterations in the range from - $38.00 \%$ to $527.54 \%$, compared to the control sample. The DSC analysis revealed the increase in melting point of the treated sample $\left(193.10^{\circ} \mathrm{C}\right) \mathrm{by} 1.76 \%$ compared to the control sample $\left(189.76^{\circ} \mathrm{C}\right)$ with $13.94 \%$ increase in the latent heat of fusion $(\Delta \mathrm{H})$. Also, the treated sample showed increase in the decomposition temperature by $3.96 \%$ with a significant $35.22 \%$ reduction in the enthalpy of decomposition, compared with the control sample. Besides, The TGA/DTG analysis showed the alterations in the weight loss of Biofield Energy Treated sample by $-1.03,-24.44$, and $2.35 \%$ in the $1^{\text {st }}$, $2^{\text {nd }}$, and $3^{\text {rd }}$ step, respectively. The $\mathrm{T}_{\max }$ values of the $1^{\text {st }}, 2^{\text {nd }}$, and $3^{\text {rd }}$ peaks of the Biofield Energy Treated sample were increased by $4.68,1.88$, and $4.06 \%$ compared to the control sample. The thermal analysis revealed the increase in thermal stability of the treated sample after the Biofield Energy Treatment. Additionally, the spectral analysis including FT-IR and UV-Vis analysis did not reveal any significant difference between both the samples. The overall study concluded that the Trivedi Effect ${ }^{\circledR}$ - Energy of Consciousness Healing Treatment may help in developing a different polymorphic form of copper chloride, which might have improved thermal stability and safety profile along with better bioavailability compared to the control sample.
\end{abstract}

Keywords: Copper chloride; The Trivedi Effect ${ }^{\circledR}$, Energy of Consciousness Healing Treatment; PXRD; DSC; TGA/DTG; FTIR

\section{Introduction}

The role of minerals elements in the human body plays an important role in various body functions. However, data suggest that about $98 \%$ of the human body mass is made up of nine nonmetallic elements. The essential trace elements are boron, cobalt, copper, iodine, iron, manganese, molybdenum, and zinc. Copper is defined as one of the major and essential trace element that plays an important role in the body such as iron absorption and its transport. Copper is important component of the ceruloplasmin that has a ferroxidase-like activity [1,2]. Copper deficiency results in anaemic state because bone marrow develops iron deficient in spite of having enough iron stores in the body. In addition, copper is important for normal development of the skeleton [3], functioning of the central nervous system $[4,5]$, taste sensation [6], and for skin pigmentation [4]. In addition to various human body function, copper is the third most abundant dietary trace metal after iron and zinc. Copper is also helpful in production of red and white blood cells and it is the component of various enzymatic processes. Iron can be significantly utilized in the body using copper, which is very much important for the growth of infants, development of the brain, immune system and strong bones [7]. Copper is present in many foods such as nuts, legumes, shellfish, and liver [8]. However, the malnourished infants may 
have been reported with copper deficiency along with those children that were dependent on cow's milk, which has the low content of copper [9].

Different health agencies around the world have set standards for daily copper intake in the diet, which is defined according to different stages of life such as pregnant women, infant, adult, age, sex, and children [10]. Neutropenia and hypochromic anemia have been reported due to copper deficiency. Besides, different skeletal abnormalities were also reported that include osteoporosis, thickening of cartilage in costo-chondral junctions, cupping of the metaphysis, spontaneous factures, and hair pigmentation $[11,12]$. Copper deficiency may lead to neurological derangements such ashypotonia, psychomotor retardation, and periods of apnea [13]. Therefore, WHO (World Health Organization) reported in 1973 that the daily copper oral intake should be as $30 \mu \mathrm{g} / \mathrm{kg} /$ day (about $2 \mathrm{mg} / \mathrm{kg}$ ) in normal adults and $80 \mu \mathrm{g} / \mathrm{kg} /$ day in infants [14]. Besides, the copper absorption in the body depends upon various factors such as gut absorption and its interaction with other nutrients. However, it was reported that only $40 \%$ of the oral dietary intake of copper is absorbed in stomach and duodenum [2]. Hence, copper chloride is considered as a copper supplement, which helps in maintaining the level within the body and preventing the depletion of endogenous stores as well as the deficiency symptoms. In recent days, the Biofield Energy Treatment has been a very useful approach in terms of the alteration in the absorption and bioavailability as well as the stability profile of any compound.

US National Institutes of Health (NIH) defined the term Biofield and its associated treatment approaches, which falls under Complementary and Alternative Medicine (CAM). It is defined as an organizing principle for the dynamic information flow, which regulates various biological function and homeostasis [15]. Over the past few decades, many energy healing practices has been reported significant outcomes in various clinical and non-clinical fields. National Center for Complementary and Integrative Health (NCCAM) defined different Energy Healing therapies under the sub-division of CAM with many advantages in addition to other therapies, medicines and practices [16] such as natural products, deep breathing, yoga, Tai Chi, Qi Gong, chiropractic/osteopathic manipulation, meditation, massage, special diets, homeopathy, progressive relaxation, guided imagery, acupressure, acupuncture, relaxation techniques, hypnotherapy, healing touch, movement therapy, pilates, rolfing structural integration, mindfulness, Ayurvedic medicine, traditional Chinese herbs and medicines, naturopathy, essential oils, aromatherapy, Reiki, cranial sacral therapy and applied prayer (as is common in all religions, like Christianity, Hinduism, Buddhism, and Judaism) $[17,18]$. Biofield Healing Treatment as a CAM reported with significant results in biological studies [19].

In addition, Biofield Energy Healing Treatment (the Trivedi Effect $^{\circledR}$ ) by renowned Biofield Energy Healer has been reported and compared with significant outcomes. Hence, Biofield Energy
Healing is increasingly promoted and accepted worldwide in order to promote human wellness and improve quality of life [20]. The Trivedi Effect ${ }^{\circledR}$-Consciousness Energy Healing Treatment has been reported with significant results in the field of chemistry [21,22], pre-clinical pharmacology [23], and pharmaceutical compounds [24], skin health $[25,26]$ and many more. Thus, the objective of this study was to determine the effect of Biofield Energy Treatment (the Trivedi Effect ${ }^{\circledR}$ ) on the physicochemical, thermal, and spectroscopic properties of copper chloride with the help of various analytical techniques such as, powder X-ray diffraction (PXRD), differential scanning calorimetry (DSC), thermogravimetric analysis (TGA), FT-IR, and UV-visible spectroscopy.

\section{Materials and Methods}

\section{Chemicals and Reagents}

Copper (II) chloride (cupric chloride) was purchased from VETEC, Sigma-Aldrich, India. All other chemicals used during the experiments were of analytical grade available in India.

\section{Consciousness Energy Healing Treatment Strategies}

The test compound i.e., copper chloride was taken and divided into two parts. In this, one part did not receive the Biofield Energy Treatment and named as control copper chloride. Besides, the other part of the test compound received the Energy of Consciousness Healing Treatment by the renowned Biofield Energy Healer, Mr. Mahendra Kumar Trivedi (USA), and it was considered as the Biofield Energy Treated copper chloride. In this process, the sample was placed under the standard laboratory conditions and the Healer provided the Trivedi Effect ${ }^{\circledR}$ - Energy of Consciousness Healing Treatment to the sample, remotely, for $\sim 3$ minutes through the Unique Energy Transmission process. Consequently, the control sample was subjected to "sham" healer under the similar laboratory conditions, who did not have any knowledge about the Biofield Energy Treatment. Later on, the control and Biofield Energy Treated samples were kept in similar sealed conditions and characterized with the help of PXRD, DSC, TGA/DTG, FTIR, and UV-Vis analytical techniques.

\section{Characterization}

\section{Powder X-ray Diffraction (PXRD) Analysis}

The PXRD analysis of control and Biofield Energy Treated samples of copper chloride was done using PANalytical X'Pert3 powder X-ray diffractometer, UK. The copper line was used as the source of radiation for diffraction of the analyte at $0.154 \mathrm{~nm}$ $\mathrm{X}$-ray wavelength that is running at $40 \mathrm{~mA}$ current and $45 \mathrm{kV}$ voltage. The instrument uses a scanning rate of $18.87^{\circ} /$ second over a $2 \theta$ range of $3-90^{\circ}$ and the ratio of $\mathrm{K} \alpha-2$ and $\mathrm{K} \alpha-1$ was 0.5 (k, equipment constant). The data was collected using X'Pert data collector and X'Pert high score plus processing software in the form of a chart of the Bragg angle $(2 \theta) v s$. intensity (counts 
per second), and a detailed table containing information on peak intensity counts, d value $(\AA)$, full width half maximum (FWHM) $\left({ }^{\circ} 2 \theta\right)$, relative intensity $(\%)$, and area (cts*o $2 \theta$ ). The crystallite size (G) was calculated by using the Scherrer equation (1) as follows:

$$
G=k \lambda /(b \operatorname{Cos} \theta)
$$

Where, $\mathrm{k}$ is the equipment constant (0.5), $\lambda$ is the X-ray wavelength $(0.154 \mathrm{~nm})$; $\mathrm{b}$ in radians is the full width at half of the peaks and $\theta$ is the corresponding Bragg angle.

Percent change in crystallite size $(G)$ of copper chloride was calculated using following equation 2 :

$$
\% \text { change in crystallite size }=\frac{\left[G_{\text {Treated }}-G_{\text {Control }}\right]}{G_{\text {Control }}} \times 100
$$

Where, $G_{\text {Control }}$ and $G_{\text {Treated }}$ are the crystallite size of the control and Biofield Energy Treated copper chloride samples, respectively.

\section{Differential Scanning Calorimetry (DSC)}

The DSC analysis of the samples was performed using DSC Q2000 differential scanning calorimeter, USA under the dynamic nitrogen atmosphere with flow rate of $50 \mathrm{~mL} / \mathrm{min}$. For analysis, 2-4 mg sample was weighed and sealed in Aluminum pans. Further, it was equilibrated at $30^{\circ} \mathrm{C}$ and heated up to $450^{\circ} \mathrm{C}$ at the heating rate of $10^{\circ} \mathrm{C} / \mathrm{min}$ under Nitrogen gas as purge atmosphere [27]. The value for onset, end set, peak temperature, peak height (mJ or $\mathrm{mW}$ ), peak area, and change in heat (J/g) for each peak was recorded. Later on, the percent change in melting temperature (T) of the control and Biofield Energy Treated samples was calculated using following equation 3 :

$$
\% \text { change in melting temperature }=\frac{\left[T_{\text {Treated }}-T_{\text {Control }}\right]}{T_{\text {Control }}} \times 100
$$

Where, $\mathrm{T}_{\text {Control }}$ and $\mathrm{T}_{\text {Treated }}$ are the melting temperature of the control and Biofield Energy Treated copper chloride samples, respectively.

Also, the percent change in the latent heat of fusion $(\Delta \mathrm{H})$ was calculated using following equation 4 :

$\%$ change in latent heat of fusion $=\frac{\left[\Delta H_{\text {Treated }}-\Delta H_{\text {Control }}\right]}{\Delta H_{\text {Control }}} \times 100$

Where, $\Delta \mathrm{H}_{\text {Control }}$ and $\Delta \mathrm{H}_{\text {Treated }}$ are the latent heat of fusion of the control and treated copper chloride, respectively.

\section{Thermal Gravimetric Analysis (TGA) / Differential Thermogravimetric Analysis (DTG)}

TGA/DTG thermograms of control and Biofield Energy Treated copper chloride samples were obtained using TGA Q500 themoanalyzer apparatus, USA under dynamic nitrogen atmosphere $(50 \mathrm{~mL} / \mathrm{min})$. It involves the heating rate of $10^{\circ} \mathrm{C} /$ min from $25^{\circ} \mathrm{C}$ to $800^{\circ} \mathrm{C}$ and uses platinum crucible [27]. In TGA analysis, the weight loss in gram as well as percent loss for each step was recorded with respect to the initial weight of the sample.
Later on, in DTG analysis, the onset, endset, peak temperature and integral area for each peak was recorded. The percent change in weight loss $(\mathrm{W})$ was calculated using following equation 5 :

$$
\% \text { change in weight loss }=\frac{\left[W_{\text {Treated }}-W_{\text {Control }}\right]}{W_{\text {Control }}} \times 100
$$

Where, $\mathrm{W}_{\text {Control }}$ and $\mathrm{W}_{\text {Treated }}$ are the weight loss of the control and Biofield Energy Treated samples, respectively.

Also, the percent change in maximum thermal degradation temperature $\left(\mathrm{T}_{\max }\right)(\mathrm{M})$ was calculated using following equation 6:

$$
\text { \%change in } T_{\max }(M)=\frac{\left[M_{\text {Treated }}-M_{\text {Control }}\right]}{M_{\text {Control }}} \times 100
$$

Where, $\mathrm{M}_{\text {Control }}$ and $\mathrm{M}_{\text {Treated }}$ are the $\mathrm{T}_{\max }$ values of the control and Biofield Energy Treated samples, respectively.

\section{Fourier Transform Infrared (FT-IR) Spectroscopy}

FT-IR spectroscopy of copper chloride was performed on Spectrum ES Fourier transform infrared spectrometer (Perkin Elmer, USA) by using pressed $\mathrm{KBr}$ disk technique with the frequency array of $400-4000 \mathrm{~cm}^{-1}$. The technique uses $\sim 2 \mathrm{mg}$ of control sample and about $300 \mathrm{mg}$ of $\mathrm{KBr}$ as the diluent to form the pressed disk followed by running the sample in the spectrometer. The same procedure was used for the Biofield Energy Treated sample.

\section{Ultraviolet-visible Spectroscopy (UV-Vis) Analysis}

The UV-Vis spectral analysis of the control and Biofield Energy Treated copper chloride samples was carried out using Shimadzu UV-2400PC SERIES with UV Probe (Shimadzu, JAPAN). The spectrum was recorded in the wavelength range of 190-800 nm using $1 \mathrm{~cm}$ quartz cell having a slit width of $0.5 \mathrm{~nm}$. The absorbance spectra (in the range of 0.2 to 0.9 ) and wavelength of maximum absorbance $\left(\lambda_{\max }\right)$ were recorded.

\section{Results and Discussion}

\section{Powder X-ray Diffraction (PXRD) Analysis}

Figure 1 includes the PXRD diffractograms of control and Biofield Energy Treated copper chloride samples. The diffractograms of both the control and Biofield Energy Treated samples showed very intense and sharp peaks that represents the crystalline nature of the samples. Additionally, the diffractograms were analysed and the PXRD data such as Bragg angle $(2 \theta)$ relative peak intensity (\%), and FWHM were collected (Table 1) for calculating the crystallite size (G) of both the control and Biofield Energy Treated copper chloride. The Scherer equation [28] was used for the calculation of crystallite sizes across various planes in both the control and Biofield Energy Treated samples. 

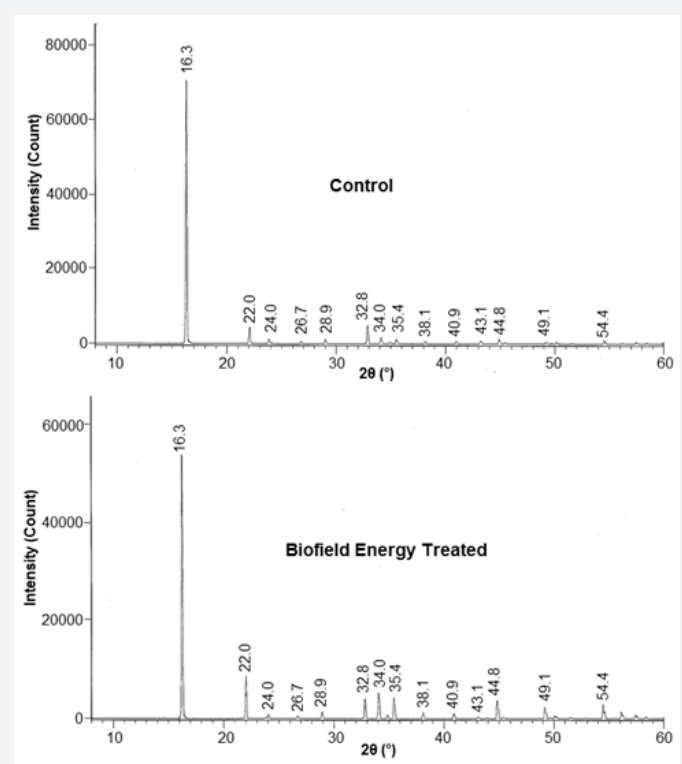

Figure 1: XRD diffractograms of the control and Biofield Energy Treated copper chloride.

Table 1: PXRD data for the control and Biofield Energy Treated copper chloride.

\begin{tabular}{|c|c|c|c|c|c|c|c|}
\hline \multirow{2}{*}{ Entry No. } & \multirow{2}{*}{ Bragg angle $(\mathbf{2} \boldsymbol{\theta})$} & \multicolumn{3}{|c|}{ Relative Peak Intensity (\%) } & \multicolumn{4}{|c|}{ Crystallite size (G, nm) } \\
\cline { 3 - 8 } & & Control & Treated & \% change & Control & Treated $^{\mathrm{a}}$ & \% change \\
\hline 1 & 16.3 & 100 & 100 & 0.00 & 31.60 & 31.60 & 0.00 \\
\hline 2 & 22.0 & 6.20 & 16.07 & 159.19 & 29.21 & 29.21 & 0.00 \\
\hline 3 & 24.0 & 0.38 & 1.64 & 331.58 & 29.32 & 31.98 & 9.08 \\
\hline 4 & 26.7 & 0.82 & 0.89 & 8.54 & 25.26 & 25.26 & 0.00 \\
\hline 5 & 28.9 & 1.67 & 2.52 & 50.90 & 27.34 & 27.34 & 0.00 \\
\hline 6 & 32.8 & 6.62 & 7.15 & 8.01 & 25.62 & 27.59 & 7.68 \\
\hline 7 & 34.0 & 2.31 & 9.21 & 298.70 & 21.17 & 27.68 & 30.78 \\
\hline 8 & 35.4 & 1.53 & 7.34 & 379.74 & 30.11 & 30.11 & 0.00 \\
\hline 9 & 38.1 & 0.88 & 2.19 & 148.86 & 33.1 & 30.34 & -8.35 \\
\hline 10 & 40.9 & 0.87 & 1.88 & 116.09 & 36.74 & 36.74 & 0.00 \\
\hline 11 & 43.1 & 1.00 & 0.62 & -38.00 & 30.84 & 37.01 & 20.01 \\
\hline 12 & 44.8 & 1.77 & 6.55 & 270.06 & 33.92 & 33.92 & 0.00 \\
\hline 13 & 49.1 & 0.69 & 4.33 & 527.54 & 31.03 & 38.79 & 24.99 \\
\hline 14 & 54.4 & 1.36 & 5.43 & 299.26 & 39.68 & 39.68 & 0.00 \\
\hline
\end{tabular}

${ }^{a}$ denotes the percentage change in the relative intensity of Biofield Energy Treated sample with respect to the control sample; ${ }^{b}$ denotes the percentage change in the crystallite size of Biofield Energy Treated sample with respect to the control sample.

The PXRD diffractograms of the Control and Biofield Energy Treated samples showed highest peak intensity (100\%) at Bragg's angle $(2 \theta)$ equal to $16.3^{\circ}$ (Table 1 , entry 1 ). The relative intensity of the PXRD peak at $2 \theta$ equal to $43.1^{\circ}$ (Table 1 , entry 11 ) in the Biofield Energy Treated sample was significantly decreased by $38 \%$, compared to the control sample. However, the relative intensities of the other PXRD peaks (Table 1, entry 2-10 and 12-14) in the Biofield Energy Treated sample were significantly increased in the range from $8.01 \%$ to $527.54 \%$ compared to the control sample, which showed that the Biofield Energy Treatment might increase the crystallinity of the Biofield Energy Treated copper chloride sample. Besides, it was also analysed from the data that the crystallite sizes of the Biofield Energy Treated samples of copper chloride at $2 \theta$ equal to nearly $24.0^{\circ}, 32.8^{\circ}$, $34.0^{\circ}, 43.1^{\circ}$, and $49.1^{\circ}$ (Table 1 , entry $3,6,7,11$, and 13 ) were significantly increased from $7.68 \%$ to $30.78 \%$ with respect to 
the control sample. However, the crystallite sizes of the Biofield Energy Treated sample at $2 \theta$ equal to $38.1^{\circ}$ (Table 1, entry 9) showed significant reduction by $8.35 \%$ as compared to the control sample. Also, the average crystallite size of the Biofield Energy Treated sample $(31.95 \mu \mathrm{m})$ was increased by $5.27 \%$ in comparison to the control sample $(30.35 \mu \mathrm{m})$. It is assumed that the Biofield Energy might be responsible for inducing the movement of crystallite boundaries, which causes crystal growth and thereby increased crystallite size. The significant alterations in the crystallite size and relative intensities of the Biofield Energy Treated sample indicated the modification in the crystal morphology as compared to the control sample. Some studies reported that such alteration in the crystal morphology due to changes in the relative intensities and crystallite size might indicate the presence of different polymorphs of the compounds and could be considered as the proof of polymorphic transition. Hence, the Biofield Energy Treatment probably introduced a new polymorphic form of the copper chloride with the help of energy transfer process [29]. Besides, any alteration in the crystal morphology might impact the dissolution and bioavailability profile of pharmaceutical/nutraceutical compound [30,31]. Thus, the Biofield Energy Treatment might improve the bioavailability profile of copper chloride.

\section{Differential Scanning Calorimetry (DSC) Analysis}

The DSC thermograms of the control and Biofield Energy Treated samples of copper chloride are shown in Figure 2 and the results are presented in Table 2.
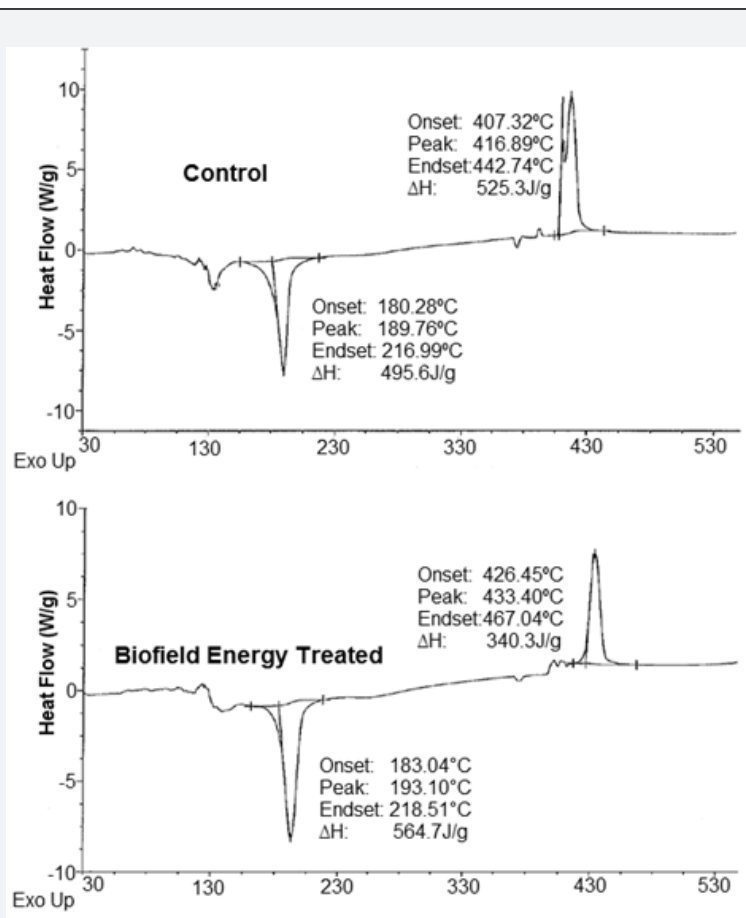

Figure 2: DSC thermograms of the control and Biofield Energy Treated copper chloride.

Table 2: Comparison of DSC data between the control and Biofield Energy Treated copper chloride.

\begin{tabular}{|c|c|c|c|c|}
\hline \multirow{2}{*}{ Sample } & \multicolumn{2}{|c|}{ Melting /Decomposition Temperature $\left.{ }^{\circ} \mathbf{C}\right)$} & \multicolumn{2}{|c|}{$\Delta \mathbf{H}(\mathrm{J} / \mathrm{g})$} \\
\cline { 2 - 5 } & $1^{\text {st }}$ Peak & $2^{\text {nd }}$ Peak & 495.60 & 525.30 \\
\hline Control & 189.76 & 416.89 & 564.70 & 340.30 \\
\hline Biofield Energy Treated & 193.10 & 433.40 & 13.94 & -35.22 \\
\hline \% Change* & 1.76 & 3.96 & ${ }^{\text {nd }}$ Peak \\
\hline
\end{tabular}

$\Delta \mathrm{H}$ : Latent heat of fusion/ Enthalpy of decomposition, *denotes the percentage change of Biofield Energy Treated sample with respect to the control sample.

The DSC thermograms of the control and Biofield Energy Treated samples of copper chloride (Figure 2) showed the presence of an endothermic as well as an exothermic peak. The
DSC curve of the control sample exhibited an endothermic peak at $189.76^{\circ} \mathrm{C}$ which represents the melting point of copper (II) chloride dihydrate [32]. However, the Biofield Energy treated 
sample showed this peak at a temperature of $193.10^{\circ} \mathrm{C}$, which was reported to be increased by $1.76 \%$ compared as the control sample (Table 3). Besides, the latent heat of fusion $(\Delta \mathrm{H})$ of the Biofield Energy Treated copper chloride was also observed to be significantly increased by $13.94 \%$ compared to the control sample. Previously, it was reported that the copper (II) chloride dihydrate got decomposed above $300^{\circ} \mathrm{C}$ along with releasing the chlorine gas [33]. In this study, the thermogram of the control sample showed a sharp exothermic peak at $416.89^{\circ} \mathrm{C}$, which was observed at higher temperature i.e., at $433.40^{\circ} \mathrm{C}$ in the Biofield Energy Treated sample; and assigned as the decomposition temperature of the copper (II) chloride dihydrate. Thus, the decomposition temperature of the Biofield Energy Treated copper chloride was found to be significantly increased by $3.96 \%$ along with a significant reduction $(35.22 \%)$ of the enthalpy of decomposition, compared with the control sample. The DSC analysis revealed that the Biofield Energy Treated copper chloride sample require different amount of energy in the form of $\Delta \mathrm{H}$ as compared to the control sample during the process of melting. Thus, it could be assumed that there might be some alterations induced by the Biofield Energy Treatment in the intermolecular forces of the compound that causes the altered
$\Delta \mathrm{H}$ in the Biofield Energy Treated sample, compared to the control sample. Moreover, it is also presumed that the Biofield Energy Treatment may be responsible for emission of less kinetic energy during the phase transition process of copper chloride from solid state to liquid state that may be responsible for increasing the $\Delta \mathrm{H}$ in the Biofield Energy Treated sample as compared to the control sample. Hence, it could be concluded that the Biofield Energy Treatment might act by altering the potential as well as the kinetic energy of the molecules of copper chloride, which possibly resulted in altered $\Delta \mathrm{H}$ and melting/decomposition temperature in the Biofield Energy Treated sample in comparison to the control sample.

\section{Thermal Gravimetric Analysis (TGA) / Differential Thermogravimetric Analysis (DTG)}

The TGA/DTG analysis helps in determining the thermal stability of the compounds with the help of the thermograms, which in this case are the control and Biofield Energy Treated samples (Figures $3 \& 4$ ). The analytical data related to the TGA and DTG analysis for the control and Biofield Energy Treated samples are mentioned in Table 3.
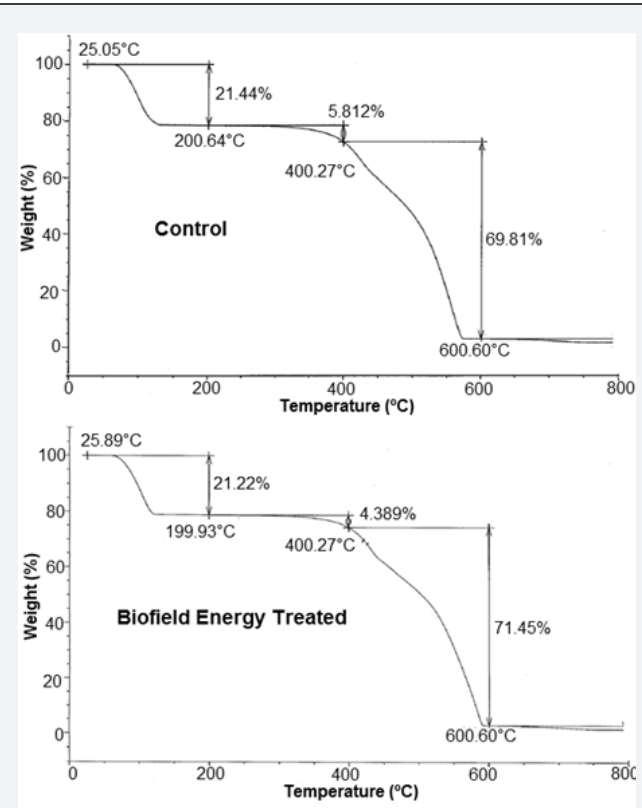

Figure 3: TGA thermograms of the control and Biofield Energy Treated copper chloride.

Table 3: Thermal degradation steps of the control and Biofield Energy Treated copper chloride.

\begin{tabular}{|c|c|c|c|c|c|c|c|}
\hline \multirow{2}{*}{ Sample } & \multicolumn{3}{|c|}{ TGA Weight loss (\%) } & \multicolumn{3}{c|}{ DTG T $\left._{\text {max }}{ }^{\circ} \mathbf{C}\right)$} \\
\cline { 2 - 8 } & $1^{\text {st }}$ step & $2^{\text {nd }}$ step & $3^{\text {rd }}$ step & Total & $1^{\text {st }}$ step & $2^{\text {nd }}$ step & $3^{\text {rd }}$ step \\
\hline Control & 21.44 & 5.81 & 69.81 & 97.06 & 99.60 & 420.4 & 561.01 \\
\hline Biofield Energy Treated & 21.22 & 4.39 & 71.45 & 97.06 & 104.26 & 428.32 & 583.77 \\
\hline \% change* & -1.03 & -24.44 & 2.35 & 0.00 & 4.68 & 1.88 & 4.06 \\
\hline
\end{tabular}

$\mathrm{T}_{\max }:$ Maximum thermal degradation temperature, *denotes the percentage change in the weight loss of Biofield Energy Treated sample with respect to the control sample. 

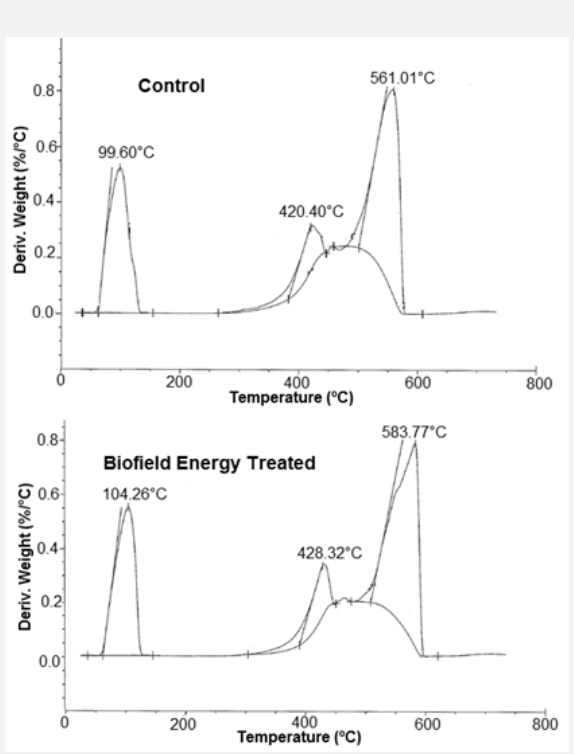

Figure 4: DTG thermograms of the control and Biofield Energy Treated copper chloride.

The thermal degradation of copper chloride dihydrate salt was reported to be occurred in various steps, as firstly the compound loses its water molecules under a dynamic nitrogen atmosphere in the temperature range of 66 to $132^{\circ} \mathrm{C}$ at $10^{\circ} \mathrm{C} / \mathrm{min}$ heating rate [32]. In this study, the TGA thermograms of the control and Biofield Energy Treated copper chloride showed three steps of thermal degradation (Figure 3 ). The analysis showed that in the $1^{\text {st }}$ and $2^{\text {nd }}$ step of degradation, the Biofield Energy Treated copper chloride has reduced weight loss by $1.03 \%$ and $24.44 \%$, respectively; while it was increased by $2.35 \%$ in the 3rd step of degradation, as compared to the control sample (Table 3). However, the overall weight loss after thermal degradation was same for both the control and the Biofield Energy Treated sample. It revealed that the Biofield Energy Treated sample possessed significant higher stability till the $2^{\text {nd }}$ step of degradation, as compared to the control sample.

Besides, the DTG thermograms of the control and Biofield Energy Treated samples (Figure 4) exhibited three peaks. The Tmax values of the $1^{\text {st }}, 2^{\text {nd }}$, and $3^{\text {rd }}$ peaks of the Biofield Energy Treated sample were increased by $4.68,1.88$, and $4.06 \%$ compared to the control sample (Table 2). Overall, TGA/DTG revealed that the thermal stability of the Biofield Energy Treated copper chloride was significantly improved, compared to the control sample, which was also supported by the DSC analysis.

\section{Fourier Transform Infrared (FT-IR) Spectroscopy}

The FT-IR spectra of control and Biofield Energy Treated samples of copper chloride are presented in Figure 5.

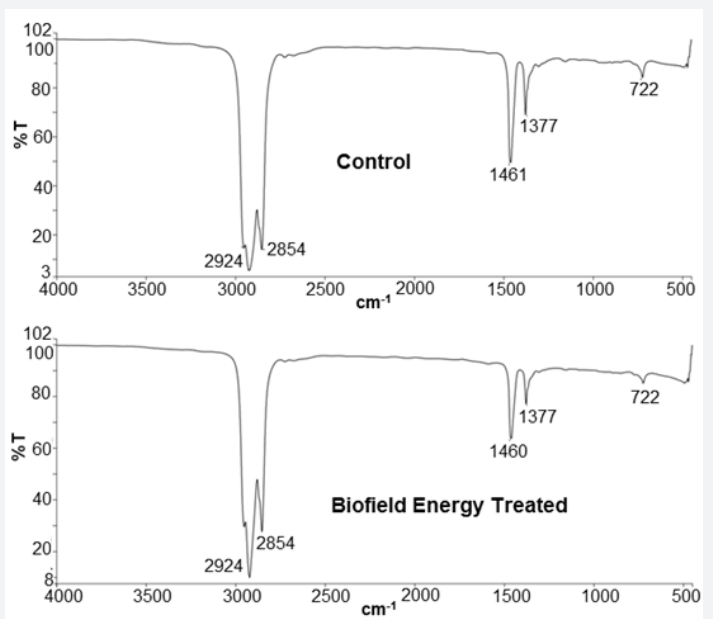

Figure 5: FT-IR spectra of the control and Biofield Energy Treated copper chloride. 
There were clear stretching and bending peaks in the functional group and fingerprint region in the FT-IR spectra of both the control and Biofield Energy Treated copper chloride (Figure 5). There were peaks at $2924 \mathrm{~cm}^{-1}$ and $2854 \mathrm{~cm}^{-1}$ in the spectra of both the control and Biofield Energy Treated sample, which were assigned to the aliphatic $\mathrm{C}-\mathrm{H}$ stretching. Besides, there were stretching frequencies in the fingerprint region of the control sample's spectrum at and in the Biofield Energy Treated samples at $1377 \mathrm{~cm}^{-1}$ and $1460 \mathrm{~cm}^{-1}$. According to the literature, the metal halide stretching absorption band was found in the frequency region $750-1000 \mathrm{~cm}^{-1}$ in case of the inorganic materials.
Thus, the peak at $722 \mathrm{~cm}^{-1}$ represents the metal halide stretching. It revealed that the fingerprint region of the control and Biofield Energy Treated sample was remained same. The FT-IR spectra did not display any changes in the vibrational frequencies thus, it may be concluded that there was no alteration in the structural properties of the Biofield Energy Treated copper chloride sample as compared to the control sample.

\section{Ultraviolet-visible Spectroscopy (UV-Vis) Analysis}

The UV-visible spectra of both, the control and Biofield Energy Treated copper chloride samples are presented in Figure 6.
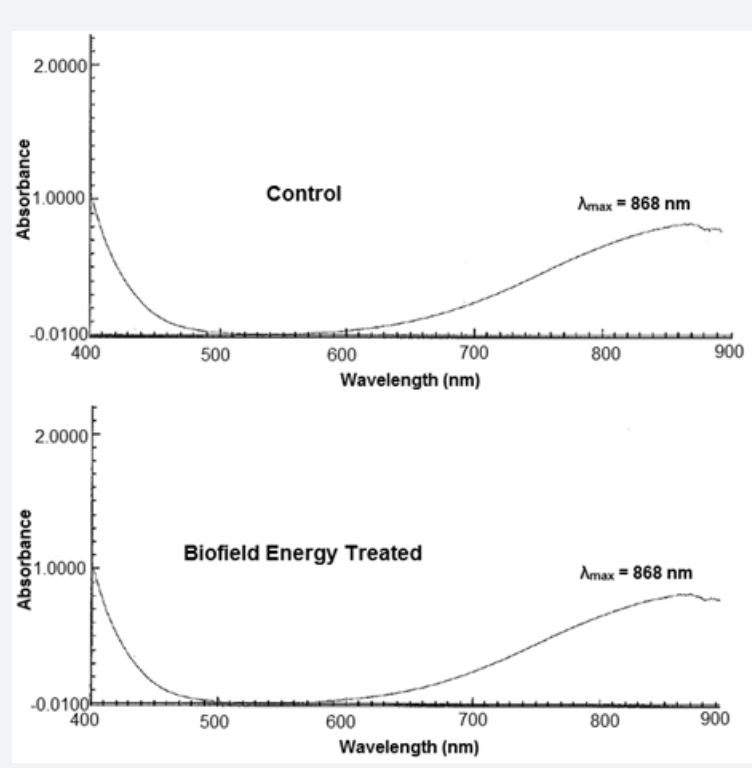

Figure 6: UV-vis spectra of the control and Biofield Energy Treated copper chloride.

The maximum absorbance $\left(\lambda_{\max }\right)$ in the UV spectra of both the control and Biofield Energy Treated samples was observed at $868 \mathrm{~nm}$. Thus, it revealed no significant alteration in the absorbance maxima between the control and Biofield Energy Treated sample. Hence, it might be concluded that there was no significant alteration in the electronic transitions between highest occupied molecular orbital and lowest unoccupied molecular orbital [34] of the Biofield Energy Treated copper chloride sample, induced by the Biofield Energy Treatment.

\section{Conclusion}

The overall study revealed that the Trivedi Effect ${ }^{\circledR}$-Energy of Consciousness Healing Treatment has the significant impact on the physical and thermal properties of copper chloride. The PXRD analysis revealed the alterations in the relative peak intensities of the Biofield Energy Treated sample in the range from $-38.00 \%$ to $527.54 \%$, as compared to the control sample. The similar alterations were observed in the crystallite sizes across various planes of the Biofield Field Energy Treated sample in the range from $-8.35 \%$ to $30.78 \%$ along with $5.27 \%$ increase in the average crystallite size, as compared to the control sample. Such alterations in the relative peak intensities and crystallite sizes along the characteristic peaks of the Biofield Energy Treated sample suggested that the Biofield Energy Treatment might create some disturbances in the crystallinity as well as the pattern of the atoms across those planes. Besides, the DSC analysis of both the samples showed the thermograms including both the endothermic and exothermic peaks. The analysis revealed that the melting point of the Biofield Energy Treated sample $\left(193.10^{\circ} \mathrm{C}\right)$ was increased by $1.76 \%$ as compared to the control sample $\left(189.76^{\circ} \mathrm{C}\right)$ along with $13.94 \%$ increase in the latent heat of fusion. Also, the data showed that the decomposition temperature of the Biofield Energy Treated sample $\left(433.40^{\circ} \mathrm{C}\right)$ was increased by $3.96 \%$ as compared to the control sample $\left(416.89^{\circ} \mathrm{C}\right)$ along with $35.22 \%$ reduction in the enthalpy of decomposition. The overall DSC data showed that the thermal stability of the Biofield Energy Treated sample was improved, as compared to the control sample. Moreover, the TGA analysis of the copper chloride samples revealed three steps of 
thermal degradation in which, the Biofield Energy Treated sample showed significant reduction in the percentage weight loss in the $1^{\text {st }}$ and $2^{\text {nd }}$ steps of degradation by 1.03 and $24.44 \%$, respectively; while it was increased by $2.35 \%$ in the $3^{\text {rd }}$ step of degradation, as compared to the control sample. The $\mathrm{T}_{\text {max }}$ values of the $1^{\text {st }}, 2^{\text {nd }}$, and $3^{\text {rd }}$ peaks of the Biofield Energy Treated sample were increased by $4.68,1.88$, and $4.06 \%$ compared to the control sample. The overall thermal analysis showed that the thermal stability of the Biofield Energy Treated copper chloride was increased along with significant alterations in the internal energy of the molecules after the Biofield Energy Treatment. However, the FT-IR spectrum and UV-Vis analysis showed similar spectral pattern between the control and Biofield Energy Treated sample. Overall, the current analysis represented the significant impact of the Trivedi Effect ${ }^{\circledR}$ Energy of Consciousness Healing Treatment on the physical and thermal properties of copper chloride. The Biofield Energy Treatment affected the crystallite size and crystallinity of the compound that might create a new polymorphic form of copper chloride. Additionally, the Trivedi Effect $^{\circledR}$ showed its potential impact in increasing the thermal stability and internal kinetic energy of drugs which may help in designing the formulations having enhanced bioavailability, safety and stability profile. Therefore, the Biofield Energy Treated copper chloride may show better response against the copper deficiency and related diseases such as anemia, osteoporosis, pigmentation of skin, apnea, psychomotor retardation, hypotonia, etc.

\section{Acknowledgement}

The authors are grateful to GVK Biosciences Pvt. Ltd., Trivedi Science, Trivedi Global, Inc., and Trivedi Master Wellness for their assistance and support during this work.

\section{References}

1. Osaki S, Johnson DA, Frieden E (1966) The possible significance of the ferrous oxidase activity of ceruloplasmin in normal human serum. J Biol Chem 241(12): 2746-2751.

2. Mason KE (1979) A conspectus of research on copper metabolism and requirements of man. J Nutr 109(11): 1979- 2066.

3. Grisoom NT, Craig JN, Neuhauser EDB (1971) Systemic bone disease developing in small premature infants. Pediatrics 48(6): 883-895.

4. Ashkenazi A, Levin S, Djaldetti M, Fishel E, Benvenisti D (1973) The syndrome of neonatal copper deficiency. Pediatrics 52(4): 525- 533.

5. Underwood EJ (1971) Trace Elements in Human and Animal Nutrition. $4^{\text {th }}$ ed. New York, Academic.

6. Henkin RL, Keiser HR, Jaffe A, Sternlieb I, Scheinberg IH (1967) Decreased taste sensitivity after D- penicillamine reversed by copper administration. Lancet 2(77529): 1268-1270.

7. Linder MC, Hazegh Azam M (1996) Copper biochemistry and molecular biology. Am J Clin Nutr 63(5): 797S-811S.

8. Prohaska JR (2012) Copper. In: Erdman JW, Macdonald IA, Zeisel SH, (eds.) Present Knowledge in Nutrition $\left(10^{\text {th }}\right.$ ed) Ames: Wiley-Blackwell.

9. Cordano A (1978) Nutrition Deficiencies in Man. Copper. In: CRC
Handbook Series in Nutrition and Food. Section E. Nutritional Diseases, Recheigl M Jr (ed.) West Palm Beach, CRC Press.

10. Al Rashid RA, Spangler J (1971) Neonatal copper deficiency. N Engl J Med 285(15): 841-843.

11. Vashchenko G, MacGillivray RT (2013) Multi-copper oxidases and human iron metabolism. Nutrients 5(7): 2289-2313.

12. Uauy R, Olivares M, Gonzalez M (1998) Essentiality of copper in humans. Am J Clin Nutr 67(5): 952S-959S.

13. Shike M (1984) Copper in parenteral nutrition. Bull N Y Acad Med 60: 132-143.

14. (1973) WHO: Trace Elements in Human Nutrition. World Health Organization Technical Report, Series No. 532.

15. Jonas WB, Crawford CC (2003) Science and spiritual healing: A critical review of spiritual healing, "energy" medicine, and intentionality. Altern Ther Health Med 9(2): 56-61.

16. Ernst E, Pittler MH, Wider B, Boddy K (2008) Oxford Handbook of Complementary Medicine. In: Oxford University Press.

17. (2009) The US National Centre for Complementary and Alternative Medicine. Cam basics. What is complementary and alternative medicine? U.S: Department of Health and Human Services.

18. Anderson JG, Taylor AG (2011) Effects of healing touch in clinical practice. A systematic review of randomised clinical trials. J Holist Nurs 29(3): 221-228.

19. Zahra M, Farsi M (2009) Biofield therapies: Biophysical basis and biological regulations. Complement Ther Clin Pract 15(1): 35-37.

20. Ross CL (2019) Energy medicine: Current status and future perspectives. Glob Adv Health Med 8: 1-10.

21. Trivedi MK, Jana S (2021) Physicochemical, thermal and spectroscopic characterization of the energy of consciousness healing treated copper chloride. Aspects Min Miner Sci 6(2): 707-717.

22. Trivedi MK and Jana S (2021) Investigation of impact of biofield energy healing treatment on physicochemical, thermal and spectral properties of magnesium gluconate. Food Sci \& Nutri Tech 6(1): 000257.

23. Trivedi MK and Jana S (2021) Antioxidant activity of biofield treated proprietary formulation supplemented with vitamins and minerals in d-galactose induced aging dysfunction in Sprague Dawley rats. Cell Cellular Life Sci J 6(1): 000160.

24. Trivedi D, Trivedi MK, Branton A, Jana S (2021) Isotopic abundance ratio analysis of the consciousness energy healing treated flutamide using LC-MS and GC-MS spectrometry. J Cancer Oncol 2021 5(1): 000167.

25. Dodon J, Trivedi MK, Branton A, Trivedi D, Nayak G, et al. (2017) The study of biofield energy treatment based herbomineral formulation in skin health and function. American Journal of BioScience 5(3): 42-53.

26. Kinney JP, Trivedi MK, Branton A, Trivedi D, Nayak G, et al. (2017) Overall skin health potential of the biofield energy healing based herbomineral formulation using various skin parameters. American Journal of Life Sciences 5(2): 65-74.

27. Trivedi MK, Branton A, Trivedi D, Nayak G, Plikerd WD, et al. (2017) A systematic study of the biofield energy healing treatment on physicochemical, thermal, structural, and behavioral properties of iron sulphate. International Journal of Bioorganic Chemistry 2(3): 135-145.

28. Langford JI, Wilson AJC (1978) Scherrer after sixty years: A survey and some new results in the determination of crystallite size. J Appl Cryst 11: 102-113. 
29. Raza K, Kumar P, Ratan S, Malik R, Arora S (2014) Polymorphism: The phenomenon affecting the performance of drugs. SOJ Pharm Pharm Sci 1: 10 .

30. Blagden N, de Matas M, Gavan PT, York P (2007) Crystal engineering of active pharmaceutical ingredients to improve solubility and dissolution rates. Adv Drug Deliv Rev 59(7): 617-630.

31. Zhao Z, Xie M, Li Y, Chen A, Li G, et al. (2015) Formation of curcumin nanoparticles via solutionenhanced dispersion by supercritical $\mathrm{CO}_{2}$. Int J Nanomedicine 10: 3171-3181.
32. Mohamed MA, Halawy SA (1994) Non-isothermal kinetic and thermodynamic study for the dehydration of copper (II) chloride dihydrate and nickel chloride hexahydrate. J Thermal Anal 41: 147-159.

33. Wirtz MC (2008) Oven versus bunsen burner when heating copper (II) chloride dihydrate. J Chem Educ 85: 1345.

34. Harris DC, Bertolucci MD (1978) Symmetry and spectroscopy. An introduction to vibrational and electronic spectroscopy. Dover Publications, Inc: New York.

Your next submission with Juniper Publishers will reach you the below assets

- Quality Editorial service

- Swift Peer Review

- Reprints availability

- E-prints Service

- Manuscript Podcast for convenient understanding

- Global attainment for your research

- Manuscript accessibility in different formats

( Pdf, E-pub, Full Text, Audio)

- Unceasing customer service

Track the below URL for one-step submission https://juniperpublishers.com/online-submission.php 